DOI

\title{
УЛЬТРАЗВУКОВА ХАРАКТЕРИСТИКА ГОСТРИХ ТА ХРОНІЧНИХ НЕОДОНТОГЕННИХ ПІДНИЖНЬОЩЕЛЕПНИХ ЛІМФАДЕНІТІВ У ДІТЕЙ
}

\section{Вищий державний навчальний заклад «Українська медична стоматологічна академія», м. Полтава}

РЕЗЮМЕ. Метою роботи було вивчити особливості ультразвукової картини при гострому гнійному та хронічному гіперпластичному неодонтогенному піднижньощелепному лімфаденіті у дітей.

У результаті дослідження проведено аналіз обстеження 20 хворих на гострий гнійний одонтогенний піднижньощелепний лімфаденіт та 10 дітей, хворих на хронічний гіперпластичний неодонтогенний піднижньощелепний лімфадент, у віці від 7 до 12 років.

Зіставлення даних проведеного доплерівського сканування дозволило встановити, що на першу добу звернення від початку захворювання відмічається значна активація судинного компонента, що супроводжується підвищенням в 2,8 раза індексу резистентності, в 3,2 раза - пульсаційного індексу. Кінцева діастолічна швидкість зростала в 4,5 раза. У пацієнтів, що звернулись за допомогою на 2-3 добу від початку захворювання, мало місце зниження, порівняно з першою добою, індексу резистентності в 1,5 раза, пульсаційного індексу - в 1,3 раза, кінцевої діастолічної швидкості - в 1,5 раза, але вони не досягали показників контрольних величин. Сонографічна картина піднижньощелепних лімфатичних вузлів при хронічному гіперпластичному неодонтогенному лімфаденіті характеризувалась на момент дослідження наступними показниками: поперечний розмір становив $(0,93 \pm 0,08)$ см; передньо-задній розмір складав $(1,63 \pm 0,10)$ см; співвідношення поперечного та передньо-заднього розміру (індекс Solbiati) становило $(0,5 \pm 0,03) ;$ зображення воріт - присутнє; кортикальний шар візуалізувався; ступінь ехогенності змішаний, а саме, ізоехогенних випадків виявлено 80 \%, гіперехогенних $20 \%$; індекс резистентності склав в середньому $(0,28 \pm 0,04)$; пульсаційний індекс дорівнював $(0,42 \pm 0,06)$; кінцева діастолічна швидкість складала $(4,69 \pm 0,72) \mathrm{cm} / \mathrm{c}$.

Проведене дослідження дало можливість зробити висновки, що узагальнення даних ультразвукового сканування у хворих на гострий гнійний неодонтогенний піднижньощелепний лімфадентіт дозволяє встановити залежність ступеня активації судинного компонента від строків, які розділяють первинні клінічні прояви і час звернення за допомогою; при хронічному гіперпластичному неодонтогенному піднижньощелепному лімфаденіті діагностовані збільшені, переважно ізоехогенні лімфатичні вузли з ознаками підвищеного судинного тонусу.

КЛЮчОВІ СЛОВА: ультразвукове дослідження, діти, піднижньощелепні лімфаденіти.

Робота $€$ фрагментом науково-дослідної роботи ВДНЗ України «Українська медична стоматологічна академія» «Удосконалення патогенетичних підходів до комплексного лікування хворих на генералізований пародонтит», номер державної реєстрації $0110 \cup 000449$.

Вступ. Висока поширеність різних нозологічних форм запальних процесів щелепно-лицевої ділянки у дітей, серед яких лімфаденіти посідають одне з провідних місць, обумовлює цінність пошуку нових, досконалих методів діагностики. Серед сучасного потужного арсеналу різноманітних діагностичних засобів чинне місце займає ультрасонографія, можливості якої на сучасному рівні розвитку дозволяють виявити раніше недосяжні дослідженню структури, що дозволяють провести диференційну діагностику між багатоманітністю нозологічних форм лімфаденітів $[1,5,9]$.

Разом з тим, дані наукових праць з питання використання додаткових можливостей ультразвукового дослідження мають поверхневий характер і іноді суперечливі. Тому очевидною стає необхідність вивчення ультразвукових показників та їх систематизація залежно від нозологічної форми запалення в лімфатичному вузлі та клінічних стадій його перебігу $[2,7,8]$.

Метою дослідження було визначення осо6ливостей ультразвукової картини при гострому гнійному та хронічному гіперпластичному неодонтогенному піднижньощелепному лімфаденіті у дітей.

Матеріал і методи дослідження. Нами проведено обстеження 20 хворих на гострий гнійний одонтогенний піднижньощелепний лімфаденіт та 10 дітей, хворих на хронічний гіперпластичний неодонтогенний піднижньощелепний лімфаденіт, у віці від 7 до 12 років (хлопчиків - 17, дівчаток - 13).

Пацієнти 3 гострим гнійним лімфаденітом були поділені на 2 групи залежно від терміну звернення за медичною допомогою з часу появи перших клінічних ознак захворювання:

1 - діти, які звернулись за медичною допомогою на першу добу;

2 - діти, котрі звернулись за медичною допомогою на 2-3 добу.

До группи контролю віднесено 10 практично здорових дітей, котрі за оглядом та заключенням педіатра, останні 2 місяці не хворіли на гострі інфекційні захворювання та не вживали ніяких лікарських засобів. 
Огляди літератури, оригінальні дослідження, погляд на проблему

УзД обстеження здійснювали на апараті «ULTIMA PA» серійний номер ГPIC.941217.01313. Дослідження піднижньощелепних лімфатичних вузлів проводили при положенні хворого лежачи на спині з підкладеним під плечовий пояс валиком з одночасним розгинанням шиї. Спеціальної підготовки до обстеження зазвичай не проводили [6].

Отримані у процесі обстеження пацієнтів кількісні показники обробляли методами математичної статистики з розрахунком середніх вибіркових значень (M), дисперсії ( $\sigma)$ та помилок середніх значень (m) у групах обстежених осіб.

Вірогідність відмінностей отриманих результатів для різних груп визначали за допомогою t-критерію Стьюдента. Відмінності вважали статистично значимими при загальноприйнятій у медико-біологічних дослідженнях імовірності помилки $p<0,05$. Імовірність помилки оцінювали за таблицями Стьюдента з урахуванням розміру експериментальних груп.
Для оцінки статистичної значимості відмінностей розраховували непараметричний критерій U Манна-Уїтні, як непараметричний аналог t-критерію Стьюдента-Фішера, оскільки розподіл даних не відповідав нормальному $[3,4]$.

Результати й обговорення. За результатами ультразвукового дослідження (рис. 1), при зверненні за медичною допомогою: на першу добу після появи перших клінічних ознак поперечний розмір лімфатичного вузла в середньому становив $(1,6 \pm 0,13)$ см, передньо-задній розмір склав $(2,01 \pm 0,18) \mathrm{cm}$, а у співвідношенні (індекс Solbiati) складав $(0,77 \pm 0,02) ;$ зображення воріт - відсутнє; кортикальний шар не візуалізувався; ступінь ехогенності був змішаний, а саме, гіпоехогенних випадків було $65 \%$, анехогенних було $35 \%$; індекс резистентності (RI) склав в середньому $(0,69 \pm 0,04)$; пульсаційний індекс (PI) дорівнював $(1,11 \pm 0,08) ;$ кінцева діастолічна швидкість (КДШ) складала $(9,20 \pm 1,14) \mathrm{cm} / \mathrm{c}$.

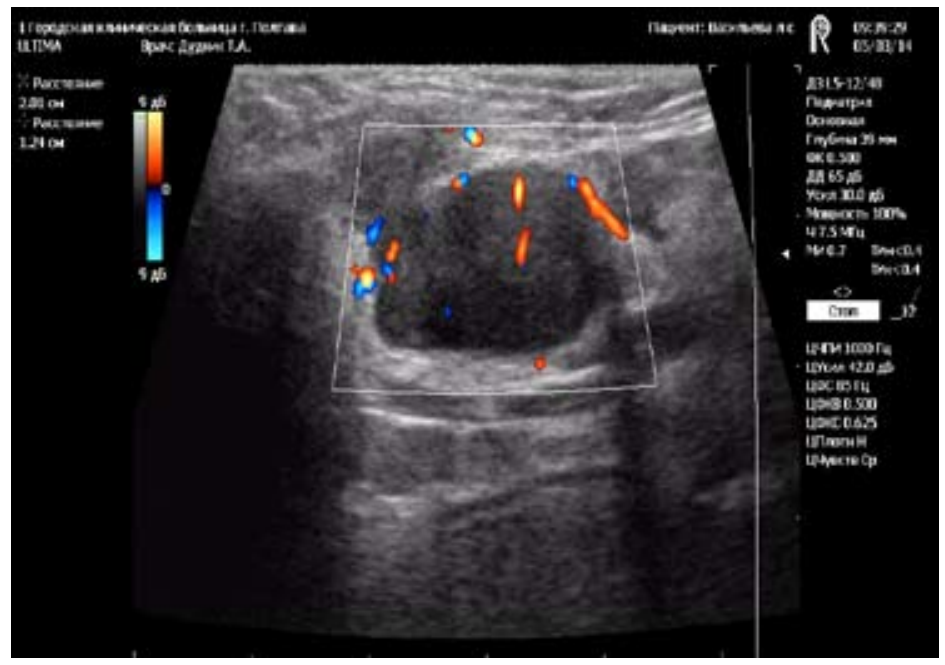

Рис. 1. Ехограма піднижньощелепного лімфатичного вузла хворого Х., 10 років (історія хвороби № 11983). Діагноз: гострий гнійний неодонтогенний піднижньощелепний лімфаденіт. Визначаються: анехогенні вогнища (1); ізоехогенні вогнища - (2); підсилення васкуляризації в режимі КДК - (3).

При зверненні на 2-3 добу від початку захворювання поперечний розмір збільшувався до $(2,04 \pm 0,20) \mathrm{cm}$, передньо-задній до $(2,52 \pm 0,15) \mathrm{cm}$, а індекс Solbiati становив $(0,79 \pm 0,04)$; зображення воріт - відсутнє; кортикальний шар не візуалізувався; ступінь ехогенності був змішаний, а саме, гіпоехогенних випадків було $60 \%$, анехогенних було $40 \%$ $\mathrm{RI}$ склав в середньому $(0,46 \pm 0,05) ;(\mathrm{PI})$ дорівнював $(0,82 \pm 0,07) ;$ КДШ складала $(6,11 \pm 0,82)$ (табл. 1).

Зіставлення даних проведеного доплерівського сканування дозволило встановити, що на першу добу звернення від початку захворювання відмічається значна активація судинного компонента, що супроводжувалось підвищенням в 2,8 раза RI, в 3,2 раза PI. Кінцева діастолічна швидкість зростала в 4,5 раза. У пацієнтів, що зверну- лись за допомогою на 2-3 добу від початку захворювання, мало місце зниження порівняно 3 першою добою, RI в 1,5 раза, PI в 1,3 раза, кінцевої діастолічної швидкості в 1,5 раза, але вони не досягали показників контрольних величин. Сонографічна картина піднижньощелепних лімфатичних вузлів при хронічному гіперпластичному неодонтогенному лімфаденіті (рис. 2) характеризувалась на момент дослідження наступними показниками: поперечний розмір становив $(0,93 \pm 0,08)$ см; передньо-задній розмір складав $(1,63 \pm 0,10)$ см; співвідношення поперечного та передньо-заднього розміру (індекс Solbiati) становило $(0,5 \pm 0,03)$; зображення воріт - присутнє; кортикалний шар візуалізувався; ступінь ехогенності змішаний, а саме ізоехогенних випадків виявле- 
Огляди літератури, оригінальні дослідження, погляд на проблему

Таблиця 1. Показники ультразвукового дослідження хворих на гострий гнійний неодонтогенний піднижньощелепний лімфаденіт $(\mathrm{M} \pm \mathrm{m})$

\begin{tabular}{|c|c|c|c|}
\hline Показники & $\begin{array}{l}\text { Контрольна } \\
\text { група } \\
(n=10)\end{array}$ & $\begin{array}{c}\text { Гострий гнійний неодонтогенний } \\
\text { лімфаденіт (перша доба звернення) } \\
(\mathrm{n}=10)\end{array}$ & $\begin{array}{c}\text { Гострий гнійний неодонтогенний } \\
\text { лімфаденіт (2-3 доба звернення) } \\
(\mathrm{n}=10)\end{array}$ \\
\hline $\begin{array}{c}\text { Поперечний розмір, } \\
\text { см }\end{array}$ & $0,62 \pm 0,03$ & $\begin{array}{l}1,60 \pm 0,13 \\
\mathrm{P}_{1}<0,001\end{array}$ & $\begin{array}{c}2,04 \pm 0,20 \\
P_{1}<0,001 \\
P_{2}>0,05\end{array}$ \\
\hline $\begin{array}{c}\text { Передньо-задній } \\
\text { розмір, см }\end{array}$ & $1,19 \pm 0,07$ & $\begin{array}{l}2,01 \pm 0,18 \\
p_{1}<0,001\end{array}$ & $\begin{array}{l}2,52 \pm 0,15 \\
P_{1}<0,001 \\
P_{2}<0,05\end{array}$ \\
\hline $\begin{array}{l}\text { Індекс Solbiati } \\
\text { (П/ПЗ), ум. од. }\end{array}$ & $0,53 \pm 0,04$ & $\begin{array}{l}0,77 \pm 0,02 \\
\mathrm{P}_{1}<0,001\end{array}$ & $\begin{array}{l}0,79 \pm 0,04 \\
P_{1}<0,001 \\
P_{2}<0,05 \\
\end{array}$ \\
\hline Зображення воріт & Присутнє & Відсутнє & Відсутнє \\
\hline $\begin{array}{c}\text { Візуалізація } \\
\text { кортикального шару }\end{array}$ & Візуалізується & Не візуалізується & Не візуалізується \\
\hline Ступінь ехогенності & Ізоехогенна & $\begin{array}{l}\text { Ізоехогенна } 60 \% \\
\text { Анехогенна } 40 \%\end{array}$ & $\begin{array}{l}\text { Ізоехогенна } 65 \% \\
\text { Анехогенна } 35 \%\end{array}$ \\
\hline $\begin{array}{l}\text { Індекс RI } \\
\text { ум. од. }\end{array}$ & $0,25 \pm 0,04$ & $\begin{array}{l}0,69 \pm 0,04 \\
p_{1}<0,001\end{array}$ & $\begin{array}{l}0,46 \pm 0,05 \\
\mathrm{P}_{1}<0,005 \\
\mathrm{P}_{2}<0,005\end{array}$ \\
\hline $\begin{array}{l}\text { Індекс PI } \\
\text { ум. од. }\end{array}$ & $0,35 \pm 0,05$ & $\begin{array}{l}1,11 \pm 0,08 \\
p_{1}<0,001\end{array}$ & $\begin{array}{l}0,82 \pm 0,07 \\
P_{1}<0,001 \\
P_{2}<0,02\end{array}$ \\
\hline $\begin{array}{c}\text { Кінцева діастолічна } \\
\text { швидкість (КДШ), } \\
\text { см/с }\end{array}$ & $2,03 \pm 0,21$ & $\begin{array}{l}9,20 \pm 1,14 \\
p_{1}<0,001\end{array}$ & $\begin{array}{l}6,11 \pm 0,82 \\
p_{1}<0,001 \\
p_{2}<0,05\end{array}$ \\
\hline
\end{tabular}

Примітки:

1 - $\mathrm{p}_{1}$ - показник статистичної значимості відмінностей між показниками контрольної групи і хворими на гострий гнійний неодонтогенний лімфаденіт.

2 - $\mathrm{p}_{2}$ - показник статистичної значимості відмінностей між показниками хворих на гострий гнійний неодонтогенний лімфаденіт при зверненні на 1 добу та хворими на гострий гнійний неодонтогенний лімфаденіт при зверненні на 2-3 добу.

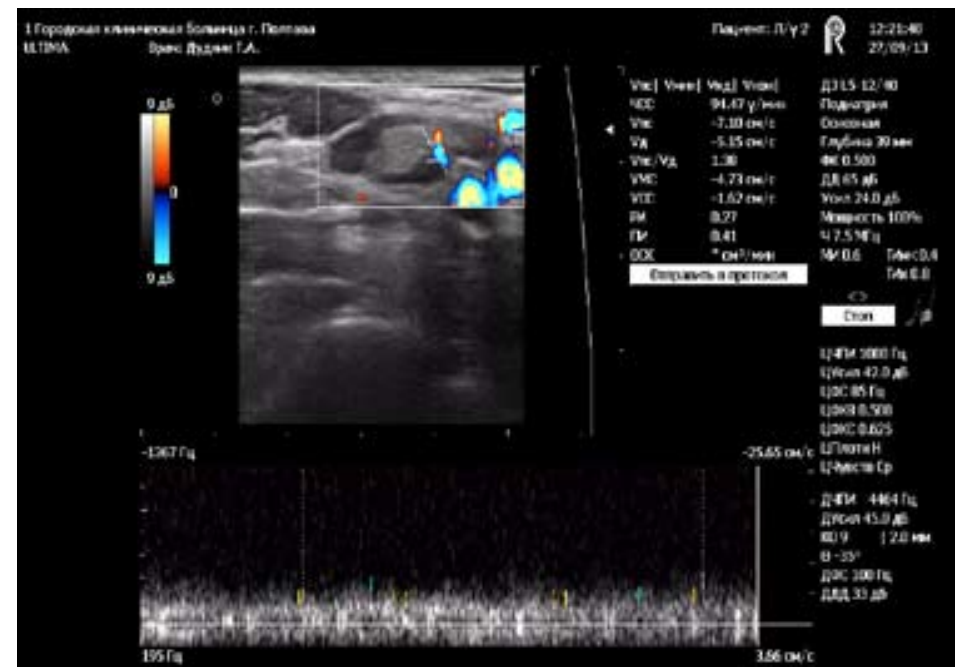

Рис. 2. Ультразвукове зображення піднижньощелепного лімфатичного вузла хворого К., 9 років (амбулаторна картка № 584). Діагноз: хронічний гіперпластичний неодонтогенний піднижньощелепний лімфаденіт. Визначається: підсилення кровотоку із збільшенням швидкості.

но 80 \%, гіперехогенних 20 \%; RI склав в середньо- діастолічна швидкість складала $(4,69 \pm 0,72)$ см/с мy $(0,28 \pm 0,04) ;$ P дорівнював $(0,42 \pm 0,06) ;$ кінцева (табл. 2). 
Огляди літератури, оригінальні дослідження, погляд на проблему

Таблиця 2. Показники ультразвукового дослідження хворих на хронічний гіперпластичний неодонтогенний піднижньощелепний лімфаденіт $(\mathrm{M} \pm \mathrm{m})$

\begin{tabular}{|c|c|c|}
\hline Показники & $\begin{array}{c}\text { Контрольна група } \\
(n=10)\end{array}$ & $\begin{array}{c}\text { Хронічний гіперпластичний неодонтогенний } \\
\text { піднижньощелепний лімфаденіт } \\
(\mathrm{n}=10)\end{array}$ \\
\hline Поперечний розмір, см & $0,62 \pm 0,03$ & $\begin{array}{l}0,93 \pm 0,08 \\
\mathrm{P}_{1}<0,002\end{array}$ \\
\hline $\begin{array}{c}\text { Передньо-задній розмір, } \\
\text { см }\end{array}$ & $1,19 \pm 0,07$ & $\begin{array}{l}1,63 \pm 0,10 \\
p_{1}<0,005\end{array}$ \\
\hline $\begin{array}{l}\text { Індекс Solbiati } \\
\text { (П/ПЗ), ум. од. }\end{array}$ & $0,53 \pm 0,04$ & $\begin{array}{l}0,5 \pm 0,03 \\
p_{1}>0,05\end{array}$ \\
\hline Зображення воріт & Присутнє & Присутнє \\
\hline $\begin{array}{c}\text { Візуалізація } \\
\text { кортикального шару }\end{array}$ & Візуалізується & Візуалізується \\
\hline Ступінь ехогенності & Ізоехогенна & $\begin{array}{c}\text { Змішана: } \\
\text { Ізоехоегенна } 80 \% \\
\text { Гіперехогенна } 20 \%\end{array}$ \\
\hline $\begin{array}{l}\text { Індекс RI, } \\
\text { ум. од. }\end{array}$ & $0,25 \pm 0,04$ & $\begin{array}{c}0,28 \pm 0,04 \\
\mathrm{P}_{1}>0,05\end{array}$ \\
\hline $\begin{array}{l}\text { Індекс PI, } \\
\text { ум. од. }\end{array}$ & $0,35 \pm 0,05$ & $\begin{array}{c}0,42 \pm 0,06 \\
p_{1}>0,05\end{array}$ \\
\hline $\begin{array}{c}\text { Кінцева діастолічна } \\
\text { швидкість (КДШ), см/с }\end{array}$ & $2,03 \pm 0,21$ & $\begin{array}{c}3,08 \pm 0,54 \\
p_{1}>0,05\end{array}$ \\
\hline
\end{tabular}

Примітка: $\mathrm{p}_{1}$ - показник статистичної значимості різниці між показниками контрольної групи і хворими на хронічний гіперпластичний неодонтогенний піднижньощелепний лімфаденіт.

Висновки. 1. Узагальнення даних ультразвукового сканування у хворих на гострий гнійний неодонтогенний піднижньощелепний лімфадентіт дозволило встановити залежність ступеня активації судинного компонента від строків, які розділяють первинні клінічні прояви і час звернення за допомогою.

2. При ультразвуковому дослідженні хворих на хронічний гіперпластичний неодонтогенний піднижньощелепний лімфаденіт виявлялись збільшені, переважно ізоехогенні, лімфатичні вузли з ознаками підвищенного судинного тонусу.

Перспективи подальших досліджень. Зважаючи на вищевикладене, виникає нагальна потреба у продовженні досліджень з ультразвукової діагностики неодонтогенних гострих та хронічних піднижньощелепних лімфаденітів у дітей та проведення кореляційного аналізу ультразвукових характеристик при гострих та хронічних піднижньощелепних лімфаденітах у дітей.

\section{ЛІТЕРАТУРА}

1. Биберман Я. М. Лимфаденит челюстнолицевой области и шеи при травме и воспалительных заболеваниях / Я. М. Биберман, В. И. Чувилкин, С. Г. Ивашкевич // Стоматолог. - 2008. - № 4. С. $12-17$.

2. Выклюк М. В. Возможности ультразвукового исследования в дифференциальной диагностике патологии лимфатического аппарата головы и шеи у детей / М. В. Выклюк // Кубанский научный медицинский вестник. - 2010. - № 1. - С. 19-21.

3. Гланц С. Медико-биологическая статистика / С. Гланц ; пер. с англ. - М. : Практика, 1998. - 459 с.

4. Гублер Е. В. Вычислительные методы распознавания патологических процессов / Е. В. Гублер. - Л. : Медицина, 1970. - 319 с.

5. Дрегалкина А. А. Частота встречаемости и структура лимфаденитов челюстно-лицевой области и шеи /

А. А. Дрегалкина, Л. Д. Герасимова, И. В. Чантырь // Проблемы стоматологии. - 2010. - № 4. - С. 40-41.

6. Заболотская Н. В. Ультразвуковое исследование лимфатической системы: клиническое руководство по ультразвуковой диагностике; - Т. 2. - под ред. В. В. Митькова, М. В. Медведева. - М. : Видар, 1996. - С. 303-329.

7. Color Doppler sonography in the evaluation of superficial lymphomatous lymph nodes / F. Giovagnorio, M. Galluzzo, C. Andreoli [et. al.] // J. Ultrasound Med. 2002. - Vol. 21 (4). - P. 403-408.

8. Does ultrasound contrast agent improve the diagnostic value of colour and power Doppler sonography in superficial lymph node enlargement? /G. Schulte-Altedorneburg, J. Demharter, R. Linne [et. al.] // Eur. J. Radiol. 2003. -Vol. 48 (3). - P. 252-257.

9. Iro H. Atlas of Head and Neck Ultrasound / H. Iro, J. Zenk. - New York: Thieme, 2013. - 247 p. 


\title{
ULTRASOUND CHARACTERISTIC OF THE ACUTE AND CHRONIC NONODONTOGENIC SUBMANDIBULAR LYMPHADENITIS IN CHILDREN
}

\author{
Higher State Educational Institution «Ukrainian Medical Stomatological Academy», Poltava
}

@I. V. Ksonz

SUMMARY. The aim of the work was to study the peculiarities of ultrasound diagnostics in the acute purulent and chronic hyperplastic non-odontogenic submandibular lymphadenitis in children.

The study has resulted in the analysis of the examination of 20 children with the acute purulent odontogenic submandibular lymphadenitis and 10 children with chronic hyperplastic non-odontogenic submandibular lymphadenitis, aged from 7 to 12 years.

Comparison of the Doppler scan data has revealed that in the first 24 hours from the onset of the disease a significant activity of the vascular component, accompanied by the increase of resistance index by 2.8 times and pulsation index by 3.2 times was noted. End-diastolic rate increased by 4.5 times. In patients that applied for medical assistance on 2-3 days from the onset, a decrease of resistance index by 1.5 times, pulsation index by 1.3 times, end-diastolic rate by 1.5 times, as compared with the first day of the referral, was observed; however, they did not reach the control values. During the investigation sonographic image of submandibular lymph nodes in chronic hyperplastic non-odontogenic lymphadenitis was characterized by the following indicators: the transverse dimension was $0.93 \pm 0.08 \mathrm{~cm}$.; anteroposterior dimension $1.63 \pm 0.10 \mathrm{~cm}$; the ratio of the transverse and anteroposterior dimensions (Solbiati index) was $0,5 \pm 0,03$, the image of the hilum was identified; cortical layer was visualized; the degree of echogenicity was mixed, isoechoic cases accounted for $80 \%$, hypoechoic cases accounted for $20 \%$, resistance index was on the average of $0.28 \pm 0.04$; pulsation index was $0.42 \pm 0.06$; end-diastolic rate was $4.69 \pm 0.72 \mathrm{~cm} / \mathrm{s}$.

The study have concluded that the synthesis of ultrasonic data of patients with acute purulent nonodontogenic submandibular lymphadenitis facilitates determining the degree of dependence of the activation of the vascular component from the time periods that distinguish the initial clinical manifestations and the time of applying for medical assistance; and enlarged, mainly isoechoic lymph nodes, with signs of high vascular tone are diagnosed in chronic hyperplastic nonodontogenic submandibular lymphadenitis diagnosed.

KEY WORDS: ultrasonography, children, submandibular lymphadenitis. 